\title{
ACCRUALS MANAGEMENT, INVESTOR SOPHISTICATION, AND EQUITY VALUATION: EVIDENCE FROM 10-Q FILINGS
}

\author{
Steven Balsam \\ Fox School of Business and Management \\ Temple University \\ Philadelphia, PA 19122 \\ Eli Bartov and Carol Marquardt \\ Leonard N. Stern School of Business \\ New York University \\ New York, NY 10012
}

June 2000

We would like to acknowledge comments from workshop participants at Ben Gurion University-Israel, University of Cincinnati, City University-Hong Kong, Nanyang Technological University-Singapore, the Joint NYU-Columbia Workshop, and the Spring 2000 Conference of the Chicago Quantitative Alliance. 


\section{ACCRUALS MANAGEMENT, INVESTOR SOPHISTICATION, AND EQUITY VALUATION: EVIDENCE FROM 10-Q FILINGS}

\section{Introduction}

Earnings management has been drawing renewed attention from the financial press, investors, and regulators. Recent reports in the Wall Street Journal, for example, claim that there has been a major shift in investor psychology on earnings management. ${ }^{1}$ While meeting earnings estimates used to be considered a "badge of honor," the market now looks more skeptically at earnings reports that reach their targets through questionable means. In fact, there have recently been several instances where firms have experienced steep stock price declines around quarterly earnings announcements due to investor concerns over earnings quality.

Regulators have also expressed recently apprehension over earnings management. In a 1998 speech, Securities and Exchange Commission (SEC) Chairman Arthur Levitt identified a host of accounting practices that were eroding the quality of earnings reports and launched a sweeping campaign against earnings management. ${ }^{2}$ Similar concerns in 1999 led the American Institute of Certified Public Accountants (AICPA) to adopt new independence requirements for auditors that are aimed at toughening their objectivity and the New York Stock Exchange (NYSE) to propose a rule change regarding the audit committee requirements of listed companies.

Despite this widespread concern over earnings management and eroding earnings quality, prior research has not addressed the question of how the presence of earnings management might affect the stock price reaction to earnings news. If, for example,

\footnotetext{
${ }^{1}$ See, "Earnings Management Spurs Selloffs Now," The Wall Street Journal, October 29, 1999, p.C1.

${ }^{2}$ See Levitt [1998].
} 
earnings management is pervasive, one might expect a weak or nonexistent relation between stock returns and earnings news. Contrary to this notion, numerous studies over the last three decades have documented highly significant correlations between these two variables.

We extend prior research by examining the stock price reaction to quarterly earnings news for a sample of firms for which there is ex post evidence of earnings management. We identify these firms using two criteria. First, we require that sample firms meet or just beat quarterly earnings expectations as measured by consensus analyst forecasts. Given that prior research has shown that firms are averse to missing these forecasts, it is more likely that these firms have managed accruals in order to meet this benchmark. Consequently, investors are more likely to scrutinize these earnings reports particularly carefully, using, among other sources, 10-Q information. Second, we require that our measure of the sample firms' unexpected discretionary accrual component for the quarter in question is at least one percent of total assets. Given the measurement error inherent in discretionary accrual estimation, this requirement helps to eliminate firms that are less likely to have managed earnings. Furthermore, a relatively large discretionary component of earnings helps to assure that investors are able to detect its presence. Limiting our sample to this subset of firms therefore increases the likelihood that investors will detect earnings management for our sample firms, if it exists.

Because we rely upon discretionary accruals to detect earnings management and because the data necessary to compute the discretionary and nondiscretionary components of earnings is typically not available to investors until some time after quarterly earnings figures are announced, we focus our analysis around the dates that 
Form 10-Q quarterly reports are filed with the SEC. ${ }^{3}$ Quarterly earnings announcements usually precede 10-Q filing dates by as much as several weeks, and therefore stock prices at the filing date have likely already incorporated the information contained in the earnings figure alone. The release of the full set of quarterly financial statements in the 10-Q provides the market with the data necessary to compute the discretionary and nondiscretionary components of earnings, thereby allowing investors to better assess the quality of the previously reported earnings number. A negative association between unexpected discretionary accruals computed using $10-\mathrm{Q}$ data and stock returns around the filing date will provide direct evidence that investors revise their assessment of earnings based on this information.

In addition to examining our primary research question, we also examine whether the extent of this reassessment of earnings integrity varies with investor sophistication. We assert that sophisticated investors may be able to recognize earnings management more quickly or more easily than unsophisticated investors. For example, sophisticated investors may recognize earnings management prior to the release of Form 10-Q because they have access to other, more timely sources of information (e.g., conference calls and private conversations with management). If this were the case, their reaction to accruals management would precede the $10-\mathrm{Q}$ filing date, leaving only the unsophisticated investors to respond around the 10-Q filing. Another possibility is that sophisticated investors are more easily able than unsophisticated investors to decompose earnings into its discretionary and nondiscretionary components using 10-Q information. This would

\footnotetext{
${ }^{3}$ Within 45 days of the end of each of the first three fiscal quarters of each fiscal year, a publicly traded company must file quarterly financial statements with the SEC on Form 10-Q. In contrast, a firm has 90 days after the end of the fourth quarter to file its annual $10-\mathrm{K}$ report.
} 
suggest that only sophisticated investors react to the information in Form 10-Q, with unsophisticated investors responding some time after the filing date. In both cases we expect the reaction of the sophisticated investors to precede that of the unsophisticated investors.

Consistent with our expectations, we document a negative association between unexpected discretionary accruals and cumulative abnormal returns (CAR) over a 17-day window around the filing date of Form 10-Q. Using institutional investor ownership as a proxy for investor sophistication, we also find that this association varies systematically across firms and is statistically significant only for firms whose owners are relatively unsophisticated, i.e., firms with low institutional holdings. We also document a significantly negative association between unexpected discretionary accruals and CAR over a period ending two-days prior to the filing date of $10-\mathrm{Q}$ for firms with relatively high institutional ownership, but not for other firms. Thus as expected the reaction of sophisticated investors precedes that of unsophisticated investors. However, for both types of firms no relation is observed between unexpected discretionary accruals and CAR around earnings announcements. Finally, results of portfolio tests formed on the basis of unexpected discretionary accruals indicate that the observed abnormal returns associated with the filings of 10-Qs are economically as well as statistically significant for firms with relatively low institutional ownership, but not for other firms. Together this evidence suggests that security prices behave as if sophisticated investors incorporate the valuation implications of unexpected discretionary accruals prior to the formal release of the 10-Q but not as early as the earnings announcement date. Unsophisticated 
investors are able to incorporate this information into stock prices only upon the formal release of the 10-Q.

This study contributes to the accounting literature in several ways. First, we extend prior research on the information content of earnings by specifically examining whether the presence of earnings management affects the stock price reaction to earnings information. Our evidence suggests that investors reassess reported quarterly earnings figures when additional financial statement information indicates that earnings management has occurred. Thus, for some firms, the short window around the quarterly earnings announcement may not be long enough to fully capture the market response to earnings news.

On a related note, we also provide evidence that the full set of financial statements presented in Form 10-Q is price informative for a subset of firms. Prior research (e.g., Easton and Zmijewski [1993]) had failed to find abnormal stock returns around 10-Q filing dates. By carefully limiting the sample to those firms where 10-Q disclosures are likely to be useful, we are able to document significant price effects around these events.

We also contribute to the literature on the pricing of discretionary accruals. While Teoh, et al. [1998a, 1998b] and Rangan [1998] investigate the long-run price effects of discretionary accruals, this study fills a void in the literature by examining short-window returns around 10-Q filings soon after the quarterly earnings announcement. We empirically demonstrate that prices quickly reflect the information in discretionary accruals; i.e., it does not necessarily take several years for prices to impound the effects of discretionary accruals, as suggested by prior research. Additionally, Subramanyam 
[1996] finds that on average discretionary accruals and firm value are positively correlated, but recognizes that his research design is not suited to identify discretionary accruals motivated by opportunism. Our findings show that when accruals management is more likely to be opportunistically motivated, the market responds negatively, not positively, to discretionary accruals.

Lastly, we also contribute to the literature concerning the role that investor sophistication plays in equity valuation. For example, Bartov, Radhakrishnan, and Krinsky [2000] find that post-earnings-announcement cumulative abnormal returns are negatively correlated with investor sophistication; i.e., there is less drift for firms with high institutional ownership. Rajgopal, Venkatachalam, and Jiambalvo [1999] find that discretionary accruals are negatively related to the level of institutional ownership, which is consistent with managers recognizing that institutional owners are better informed than individual investors, which reduces the perceived benefit of managing accruals. They also find that as institutional ownership increases, stock prices tend to reflect a greater proportion of the information in future earnings relative to current earnings. Our results are consistent with the overall tenor of these prior findings; i.e., sophisticated investors are better informed, and the stock prices of firms with high institutional ownership reflect this fact.

The remainder of the paper is organized as follows: Section 2 outlines our research methodology, and Section 3 describes the sample selection and data. Section 4 presents the results, and Section 5 provides concluding remarks. 


\section{Research Method}

\subsection{Experimental Design}

Our primary research question is whether the presence of earnings management affects the stock price reaction to earnings news. Specifically, we are interested in determining whether investors reassess the integrity of recently announced earnings numbers using information from the full set of financial statements. Our analysis therefore focuses on the period around the filing date of Form 10-Q, which permits the disaggregation of accruals into their discretionary and nondiscretionary components. If investors first become aware that the firm has engaged in accruals management from 10Q information, we expect a decrease in the security price of firms with positive unexpected discretionary accruals as this indicates that the recently reported quarterly earnings may have been artificially inflated. Similarly, we expect an increase in the security price of firms with negative unexpected discretionary accruals. More generally, we hypothesize a negative association between unexpected discretionary accruals and abnormal stock returns around the filing date of Form 10-Q.

To test for the predicted association between unexpected discretionary accruals and abnormal stock returns, we employ the following model:

$$
\mathrm{CAR}_{\mathrm{i}}=\alpha_{0}+\alpha_{1} \mathrm{CDACC}_{\mathrm{i}}+\varepsilon_{\mathrm{i}}
$$

where $\mathrm{CAR}_{\mathrm{i}}$ is the industry-adjusted cumulative abnormal return for firm $i$ over a 17-day window $(-1,+15)$, where day 0 is the filing date of Form 10-Q with the SEC, and $\mathrm{CDACC}_{\mathrm{i}}$ is unexpected discretionary accruals for firm $i$, i.e., the difference between discretionary accruals for the current quarter $t$ and that of quarter $t-4$, expressed as a

percentage of total assets. In terms of equation (1), our hypothesis of a negative 
association between unexpected discretionary accruals and CAR around 10-Q filings predicts a negative $\alpha_{1}$.

If investors are somehow able to detect the presence of earnings management prior to the 10-Q filing date (or are unable to do so until some time after this date), the estimated coefficient on CDACC will be insignificantly different from zero over the (-1, +15 ) window. However, we would then expect a significantly negative $\alpha_{1}$ over an interval preceding or following the filing date. To allow for this possibility, we also estimate equation (1) over three alternative windows. The first is a ten-day window around the earnings announcement date (-1EAD, +9EAD), the second is a window beginning ten day after the earnings announcement and ending two days prior to the 10-Q filing date (+10EAD, -2FD), and the third is a 17-day window beginning 16 days after the filing date $(+16,+32)$. We thus examine stock returns over a continuous interval beginning one day prior to the quarterly earnings announcement and ending 32 days after the 10-Q filing date.

Equation (1) does not consider investor sophistication. Recent studies (e.g. Bartov, et al. [2000], Rajgopal [1999], and Walther [1997]) show that investor sophistication is an important determinant of the relation between earnings and returns, which suggests a need to control for this variable. As in prior work, we also use institutional investor holdings as a proxy for investor sophistication. Equation (1) thus becomes:

$$
\mathrm{CAR}_{\mathrm{i}}=\alpha_{0}+\alpha_{1} \mathrm{CDACC}_{\mathrm{i}}+\alpha_{2} \mathrm{CDACC}_{\mathrm{i}} * \mathrm{DINST}_{\mathrm{i}}+\varepsilon_{\mathrm{i}}
$$

where CDACC*DINST is the product of our unexpected discretionary accruals variable and an indicator variable that equals one if the percentage of institutional holdings is 
above 40 percent and zero otherwise; the other variables are as in equation (1). ${ }^{4}$

The sign of $\alpha_{2}$, which captures the effect of investor sophistication on the relation between CAR and unexpected discretionary accruals, is difficult to predict. It is plausible that sophisticated investors are able to infer that accruals have been managed prior to the formal 10-Q filing using other sources of information (e.g., conference calls), whereas unsophisticated investors are able to infer the accruals management only around the $10-\mathrm{Q}$ filing. This scenario implies that the sign of $\alpha_{1}$ for the period surrounding the $10-\mathrm{Q}$ filing should be negative and that of $\alpha_{2}$ should be positive, so that the sum of the two coefficients, which represent the association for firms with sophisticated investors, will be zero. If, however, only sophisticated investors are able to decompose the earnings figure into its discretionary and nondiscretionary components using 10-Q information, and unsophisticated investors are not, then we expect $\alpha_{1}$ to be insignificantly different from zero and $\alpha_{2}$ to be negative. Lastly, if both events occur, i.e., sophisticated investors recognize accruals management prior to the 10-Q filing and unsophisticated react some time after the filing date, we expect both $\alpha_{1}$ and $\alpha_{2}$ to be close to zero. We also estimate equation (2) over the three alternative windows defined earlier.

\subsection{Estimating Unexpected Discretionary Accruals}

We estimate discretionary accruals using the cross-sectional version of the Jones [1991] model as in Defond and Jiambalvo [1994]. Total accruals are regressed on the change in sales and the level of property, plant, and equipment for each fiscal quarter

\footnotetext{
${ }^{4}$ The choice of the cutoff point for DINST represents an effort to maximize the difference between the two subsamples in terms of institutional holdings while minimizing the difference in sample size. In the next section we report the results of sensitivity tests regarding this research design choice.
} 
using all firm-quarters with the same 2-digit SIC code and December fiscal year-end. More formally, the model is as follows:

$$
\mathrm{TACC}_{\mathrm{t}} / \mathrm{A}_{\mathrm{t}-1}=\alpha_{1}\left(1 / \mathrm{A}_{\mathrm{t}-1}\right)+\alpha_{2}\left(\Delta \mathrm{REV}_{\mathrm{t}} / \mathrm{A}_{\mathrm{t}-1}\right)+\alpha_{3}\left(\mathrm{PPE}_{\mathrm{t}} / \mathrm{A}_{\mathrm{t}-1}\right)+\varepsilon_{\mathrm{t}}
$$

where $\mathrm{TACC}_{\mathrm{t}}$ is total accruals in quarter $t,{ }^{5} \Delta \mathrm{REV}_{\mathrm{t}}$ is revenues in quarter $t$ less revenues in quarter $t-1, \mathrm{PPE}_{\mathrm{t}}$ is gross property plant and equipment at the end of quarter $t, \mathrm{~A}_{\mathrm{t}-1}$ is total assets at the end of quarter $t-1$, and $\varepsilon_{\mathrm{t}}$ is the residual. The residual $\left(\varepsilon_{\mathrm{t}}\right)$ represents the discretionary portion of total accruals $\left(\mathrm{DACC}_{\mathrm{t}}\right)$.

Our choice of the Jones model follows from findings of prior research examining the relative performance of alternative discretionary accruals models, which has shown that the Jones and modified Jones model best measure the discretionary portion of total accruals, albeit imperfectly (see Dechow, Sloan, and Sweeney [1995] and Guay, Kothari, and Watts [1996]). Sample size concerns lead us to choose the cross-sectional version of the Jones model.

Investigations involving a correlation between stock returns and an informational signal (e.g., earnings) typically decompose the signal into its expected and unexpected components, as only the unexpected component (i.e., the surprise) should be correlated with the stock price change. While it is standard to use the seasonal difference in quarterly earnings as the proxy for the quarterly earnings surprise, the literature provides

\footnotetext{
${ }^{5}$ As in prior research (see, e.g., Jones [1991]), we use the balance sheet approach to compute TACC $_{t}$ as follows:

where:

$$
\mathrm{TACC}_{\mathrm{t}}=\Delta \mathrm{CA}_{\mathrm{t}}-\Delta \mathrm{Cash}_{\mathrm{t}}-\Delta \mathrm{CL}_{\mathrm{t}}+\Delta \mathrm{DCL}_{\mathrm{t}}-\mathrm{DEP}_{\mathrm{t}}
$$

$\Delta \mathrm{CA}_{\mathrm{t}}$ is the change in current assets in year $t$;

$\Delta \mathrm{Cash}_{\mathrm{t}}$ is the change in cash and cash equivalents in year $t$;

$\Delta \mathrm{CL}_{\mathrm{t}}$ is the change in current liabilities in year $t$;

$\Delta \mathrm{DCL}_{\mathrm{t}}$ is the change in debt included in current liabilities in year $t$; and $\mathrm{DEP}_{\mathrm{t}}$ is depreciation and amortization expense in year $t$.
} 
little guidance regarding the appropriate proxy for the surprise in discretionary accruals. The Jones [1991] model is designed such that discretionary accruals computed under the model are meant to represent the "surprise" component; i.e., the average discretionary accrual is zero, and any deviation from zero represents the degree of earnings management. However, recent work by Jeter and Shivakumar [1999] shows that the cross-sectional Jones model yields systematically positive (negative) estimates of abnormal accruals for firms whose cash flows are below (above) their industry median. Thus, a firm whose cash flows are consistently above or below the median may have discretionary accruals consistently different from zero, even though no earnings management has occurred. We therefore use the seasonal difference in discretionary accruals as our proxy for unexpected discretionary accruals. This measure will help to correct the bias described above. In addition, this measure of unexpected discretionary accruals is appropriate if investors perceive the process underlying discretionary accruals to be a seasonal random walk because firms use discretionary accruals to smooth seasonal effects on quarterly earnings; i.e., they use discretionary accruals to inflate (deflate) earnings in fiscal quarters in which earnings are traditionally low (high). However, we note that determining the appropriate proxy for unexpected discretionary accruals is ultimately an empirical question, and we therefore perform sensitivity tests using alternative proxies for unexpected discretionary accruals as part of our analysis. 


\section{Data}

\subsection{Sample Selection}

Table 1 outlines the sample selection process and its effect on the final sample size. Based on available Compustat, IBES, Compact Disclosure, Securities and Exchange Commission's EDGAR (Electronic Data Gathering, Analysis, and Retrieval) and CRSP data over our three year sample period, 1996-1998, the final sample of 613 firm quarters (366 distinct firms) met the following criteria: ${ }^{6}$

(a) The firm has a December fiscal year-end.

(b) Quarterly earnings per share exactly meets or exceeds by one cent per share the most recent consensus analyst forecast provided by IBES for that quarter.

(c) The absolute value of quarterly unexpected discretionary accruals is at least one percent of total assets.

(d) The firm filed Form 10-Q within 45 days of the end of the quarter, and the filing date was available on EDGAR.

(e) The 10-Q filing date was at least twelve trading days after the quarterly earnings announcement date.

We require a December fiscal year-end in (a) so that seasonal differences across the calendar year are eliminated when we use the cross-sectional Jones model to estimate discretionary accruals.

\footnotetext{
${ }^{6}$ Compustat was the source for the data required for estimating unexpected discretionary accruals. Daily stock return data to calculate cumulative abnormal returns (CAR) were available from CRSP. We obtained CAR by cumulating daily raw returns from the CRSP NYSE/AMEX or NASDAQ and subtracting the daily returns from a benchmark portfolio matched by industry, where industry is determined using two-digit SIC codes of all companies on either CRSP NYSE/AMEX or NASDAQ. Data on institutional ownership were available from Compact Disclosure. The percentage of institutional ownership was measured as of the end of quarter $t$.
} 
As previously discussed, criteria (b) and (c) are meant to identify firms for which there is ex post evidence of earnings management. The requirement in (b) that sample firms meet or just beat analyst forecasts follows from findings in Burgstahler and Eames [1998], Brown [1999], and Degeorge, Patel, and Zeckhauser [1999], who document empirical patterns in quarterly forecast errors that are consistent with the notion that "making the forecast" is an important threshold for managers. This view is also echoed in Levitt [1998], who observes, "While the problem of earnings management is not new, it has swelled in a market that is unforgiving of companies that miss their estimates. I recently read of one major U.S. company that failed to meet its so-called 'numbers' by one penny, and lost more than six percent of its stock value in one day." It is thus less likely that an earnings figure that exactly meets or narrowly beats analyst forecasts occurs by chance. The requirement in (c) of a nontrivial unexpected discretionary accrual component of earnings limits our sample to those firms that have most likely managed earnings through accruals. Small changes in discretionary accruals, such as those we have eliminated, may arise from normal variation in the accruals process and are less likely to reflect actual earnings management.

The combination of criteria (b) and (c) together thus imply that earnings management has likely occurred. In addition, both (b) and (c) play a role in assuring that earnings management, if it exists, will be detected by investors: investors may more carefully scrutinize the earnings reports of firms who meet criterion (b), and the size of unexpected discretionary accruals required in (c) allows easier recognition of the phenomenon. 
We require a timely $10-\mathrm{Q}$ filing in (d) because late filings may be interpreted by investors as reflecting bad news, and any price reaction associated with this interpretation, either around the $10-\mathrm{Q}$ due date or the actual filing date itself, would confound our results. We use EDGAR to collect the 10-Q filing dates because the availability of Form 10-Q through this service helps to assure that investors have timely access to the report. Consistent with this design choice, we limit our sample to the period, 1996-1998, as the requirement by the SEC that firms electronically file Forms 10Q became fully effective in May 6, 1996.

The requirement in (e) of at least a twelve-day lag between the earnings announcement date and the 10-Q filing date allows enough time for investors to respond to the earnings announcement before reacting to the new information released in Form 10-Q. A shorter lag would make separation of the two stock-price reactions difficult.

The numbers of observations by fiscal quarter, 204, 265, and 144 for the first, second, and third fiscal quarters, respectively, are approximately evenly distributed. The reduced number of observations for the third fiscal quarter results because our sample period covers the period January 1996 through June 1998, i.e., ends with the second quarter of 1998. The number of observations in our sample increases annually: 157 observations in 1996, 248 observations in 1997, and 208 observations in the first two fiscal quarters of 1998. This increase is likely due to our requirement that firms either meet or beat by one penny per share the IBES forecast. Findings in prior studies (see, e.g., Brown [1999]) have demonstrated that the proportion of firms that meet or just beat their earnings forecasts has increased steadily in recent years. 


\subsection{Sample Descriptive Statistics}

Table 2, Panel A, presents descriptive statistics for the full sample. Discretionary accruals range from $-14.0 \%$ to $15.1 \%$ of total assets. The range of unexpected discretionary accruals, from $-23.6 \%$ to $24.3 \%$, is wider, although fully half of the sample has absolute unexpected discretionary accruals between one and four percent of total assets. Mean and median unexpected discretionary accruals are quite close to zero due to the inclusion of both positive and negative accruals. Similarly, cumulative industryadjusted returns (CAR) over a 17-day window surrounding the 10-Q filing date range from $-31.9 \%$ to $31.5 \%$, with sample mean and median also very close to zero.

Mean (median) institutional ownership is $49.9 \%$ (52.5\%), which is slightly higher than that reported in other studies. For example, Walther [1997] reports mean (median) institutional ownership of $39.3 \%(38.3 \%)$ for a sample over the years 1980-95, and Rajgopal, et al. [1999] report a mean (median) of 35.9\% (35.2\%) for their sample over 1989-95. However, recent statistics compiled by the Board of Governors of the Federal Reserve System report mean institutional ownership of $54.3 \%$ for 1996 and $56.6 \%$ for 1997 (see Flow of Funds Accounts, March 1998), which is closer to our sample mean of $49.9 \%$, suggesting that our sample may be more representative of the average firm, at least in terms of institutional ownership.

Mean (median) firm size as measured by total assets is $\$ 3150$ (\$488) million, suggesting that the sample is comprised of mainly medium-to-large sized firms. The requirement that sample firms have IBES forecasts available has likely biased our sample towards larger firms of interest to analysts. Consistent with this observation, the mean (median) number of analysts following a firm is 7.18 (6); over half of the sample firms 
are thus relatively well-followed by analysts. Lastly, the mean (median) lag between the earnings announcement and the 10-Q filing date is 23.29 (23) calendar days, or about three weeks, with a range from 16 to 37 days.

Panels B and C of Table 2 present descriptive statistics for the top and bottom quartiles of unexpected discretionary accruals. Mean (median) unexpected discretionary accruals are $8.0 \%(5.9 \%)$ of total assets for the top quartile and $-7.5 \%(-6.0 \%)$ for the bottom; all are significantly different from zero. Consistent with our expectations, mean (median) CAR for the top quartile of accruals is significantly negative at $-1.5 \%(-1.3 \%)$; mean CAR for the bottom quartile is significantly positive at $1.3 \%$. Mean and median institutional ownership, firm size (measured by total assets), analyst following, and the lag between earnings announcement date and 10-Q filing date are not significantly different across the top and bottom quartiles, suggesting that there are no systematic differences that might interfere with the analysis that follows.

\section{Empirical Findings}

\subsection{Regression analysis}

Table 3 reports the OLS parameter estimates together with their significance levels for two regression models. The first model is equation (1), in which CARs around the 10-Q filing dates are regressed on unexpected discretionary accruals, or CDACC. The second model is equation (2), in which CARs around 10-Q filing dates are regressed on two explanatory variables: CDACC and an interactive term, CDACC*DINST, which captures the marginal effect of institutional holdings on the slope of the variable CDACC. Each model is estimated using four alternative return intervals: the day before through 
nine days after the earnings announcement date (-1EAD, +9EAD); ten days after earnings announcement through two days prior to $10-\mathrm{Q}$ filing date (+10EAD, -2FD); the day before through 15 days after the $10-\mathrm{Q}$ filing date $(-1 \mathrm{FD},+15 \mathrm{FD})$; and 16 days after through 32 days after the $10-\mathrm{Q}$ filing date $(+16 \mathrm{FD},+32 \mathrm{FD})$.

The requirement that firms electronically file Form 10-Q helps in identifying the date in which the $10-\mathrm{Q}$ information first becomes available to investors. Still, we use a 17-day return window around the 10-Q filing date-- not the three-day window often used in event studies -- for two reasons. First, EDGAR filings are posted on EDGAR at least 24 hours after the date of filing. Second, it may take a few days for investors to analyze the information. ${ }^{7}$ Still, as a sensitivity test, we also use three-day and seven-day return windows around the 10-Q filing date.

We begin our empirical investigation by estimating both models over the (-1EAD, +9EAD) return interval. As expected, the slope estimates in both models are statistically insignificant at conventional levels. This evidence suggests that at the earnings announcement date both sophisticated investors and unsophisticated investors are unable to undo the accruals management.

Next, we test equations (1) and (2) using CAR measured over the period $(+10 \mathrm{EAD},-2 \mathrm{ED})$. If sophisticated investors are able to recognize accruals management during this period, but unsophisticated investors are not, the slope estimate on CDACC should be zero in both equations but significantly negative on CDACC*DINST in equation (2). The results show that the estimates on CDACC are insignificant in both

\footnotetext{
${ }^{7}$ While too long a return window may reduce statistical power, a short window that fails to capture the stock price response ensures insignificant results. For example, Han, Jennings and Noel [1992] used a three-day window when testing for the association between stock returns around 10-Q filing dates and
} 
equations, and that the estimate on CDACC*DINST, which captures the difference in the effect of unexpected discretionary accruals on abnormal stock returns between sophisticated and unsophisticated investors, is negative $\left(\alpha_{2}=-0.14\right)$ and statistically significant $(\mathrm{p}$-value $=0.03)$. The sum of the estimates on CDACC and CDACC*DINST, $\alpha_{1}+\alpha_{2}$, which measures the total impact of unexpected discretionary accruals on abnormal stock returns for the subsample of firms with high institutional ownership, is also negative, -0.07 , but only marginally significant $(\mathrm{p}$-value $=0.08)$. Together, these two findings suggest that sophisticated investors are able to recognize accruals management prior to the formal release of Form 10-Q, while unsophisticated investors are not.

For the return interval $(-1 \mathrm{FD},+15 \mathrm{FD})$, the results for equation (1) show that the estimated coefficient on CDACC is negative, $\left(\alpha_{1}=-0.11\right)$, but only marginally significant at conventional levels ( $\mathrm{p}$-value $=0.08$ ). This weak statistical significance may follow because the effect of sophisticated investors, which is not controlled for in equation (1), confounds the findings. To assess the validity of this possibility, we turn to the results for equation (2).

The results for equation (2) show that the estimated coefficient of -0.24 on CDACC is more than twice as large (in absolute value) as that in equation (1) and is highly statistically significant $(\mathrm{p}$-value $=0.001)$. This indicates that unsophisticated investors react favorably to the news that firms had reported negative unexpected discretionary accruals (i.e., conservative earnings) and unfavorably to the news that firms had reported positive unexpected discretionary accruals (i.e., inflated earnings). The

unexpected changes in the probability of bankruptcy due to $10-\mathrm{Q}$ information. However they failed to document the predicted association, perhaps due to their use of too short a return window. 
estimated coefficient on CDACC*DINST, which captures the differential effect of unexpected discretionary accruals on abnormal stock returns between sophisticated and unsophisticated investors, is positive $\left(\alpha_{2}=0.27\right)$, and is also significant ( $\mathrm{p}$-value $\left.=0.02\right)$. Further, the sum of the two estimated coefficients, which measures the total impact of unexpected discretionary accruals on abnormal stock returns for the subsample of firms with high institutional ownership, is only 0.03 , and is insignificantly different from zero $(p$-value $=0.74)$. The results for equation $(2)$ thus indicate that the valuation implications of 10-Qs vary with the level of investor sophistication as measured by institutional ownership. The negative relation between unexpected discretionary accruals and stock prices around the release of 10-Qs is observed only for firms with relatively low institutional ownership; no relation is observed for firms with high levels of institutional ownership. One interpretation of these and the previous findings collectively is that unsophisticated investors first learn about accruals management when the 10-Qs become publicly available, whereas sophisticated investors are able to infer the accruals management by drawing on more timely sources of information (e.g., conference calls, and private conversations with management). ${ }^{8}$

To examine whether the response of unsophisticated investors to the $10-\mathrm{Q}$ information is complete, we estimate equations (1) and (2) using the CAR over the 17day period $(+16 \mathrm{FD},+32 \mathrm{FD})$ as the dependent variable. If the response during the $10-\mathrm{Q}$ release period (i.e., $-1 \mathrm{FD},+15 \mathrm{FD}$ ) is complete, all the slope estimates in both equations

\footnotetext{
${ }^{8} \mathrm{We}$ also used total asset size and analyst following as proxies for investor sophistication. There was little difference between the stock price reactions to unexpected discretionary accruals across large and small firms or across high and low analyst following, which is consistent with Walther [1997], who finds that institutional ownership provides a better measure of investor sophistication than either of these alternative proxies.
} 
should equal zero. The results support this scenario. In both equations, none of the slope estimates are statistically significant at conventional levels.

\subsection{Portfolio analysis}

To gain perspective on the economic significance of our findings, we perform a supplementary portfolio analysis. First, we partition our sample into four portfolios based on the size of unexpected discretionary accruals. Portfolio 1 consists of all firmquarters in the lowest quartile of unexpected discretionary accruals, and Portfolio 4 consists of all firm-quarters in the highest quartile of unexpected discretionary accruals. If stock prices adjust to accruals management around the release of $10-\mathrm{Q}$, then the return for Portfolio 1 should be positive and the return for Portfolio 4 should be negative over the period $(-1 \mathrm{FD},+15 \mathrm{FD})$. While this pattern should be most pronounced around the 10Q filing dates, it may also be observed in other periods (e.g., prior to the release of the $10-\mathrm{Qs}$ ), assuming that our portfolio test has enough power to separate this effect from all other influences in the data.

Table 4 presents the results of the portfolio analysis. As expected, the results show that around the release of $10-\mathrm{Qs}$, over days $(-1 \mathrm{FD},+15 \mathrm{FD})$, the mean return on the four portfolios decreases monotonically from $1.27 \%$ for Portfolio 1 (firms with the lowest unexpected discretionary accruals) to $-1.53 \%$ for Portfolio 4 (firms with the highest unexpected discretionary accruals). Additionally, while the mean return for Portfolio 1 is insignificant ( $\mathrm{p}$-value $=0.14$ ) and the mean return for Portfolio 4 is only marginally significant $(\mathrm{p}$-value $=0.09)$, the mean return for the Hedge Portfolio consisting of long positions in firms in the lowest quartile of unexpected discretionary accruals and short 
positions in firms in the highest quartile is positive, $2.80 \%$, and is statistically significant $(\mathrm{p}$-value $=0.02)$. This $2.80 \%$ return is also economically significant as it translates to an annualized return of over $50 \%{ }^{9}$

In contrast, the mean returns on Portfolio 1, Portfolio 4, and the Hedge Portfolio over other periods are markedly smaller and are generally insignificant. Overall, these portfolio tests demonstrate that the relation between abnormal stock returns and unexpected discretionary accruals estimated around the release of $10-\mathrm{Q}$ s is statistically as well as economically significant.

To further assess the economic significance of this relation, we partition each Portfolio 1 through 4 into two subsamples based on investor sophistication levels (for a total of eight portfolios). Consistent with our regression analyses, we use $40 \%$ institutional ownership as the cutoff point used to partition each Portfolio. Table 5 reports the results of this analysis. Similar to the findings in Table 4, for both low and high institutional holdings the mean return decreases monotonically between the lowest and highest discretionary accruals portfolios. The magnitudes, however, differ markedly. Specifically, when institutional holdings are low, the mean return for Portfolio 1 is $3.42 \%$ $(\mathrm{p}$-value $=0.08)$, and the mean return for Portfolio 4 is $-3.23 \%(p$-value $=0.07)$. The returns for both portfolios are substantially higher than those for the full sample. Furthermore, the mean return of $6.65 \%$ on the Hedge Portfolio is more than twice as large as that for the full sample and is statistically significant ( $\mathrm{p}$-value $=0.01)$. As expected, the results are much weaker when institutional holding is high. For example,

\footnotetext{
${ }^{9}$ We note that the information required to form the portfolios is not necessarily available to investors at the portfolios' formation dates. Therefore, the portfolio analysis in this section serves to evaluate the economic significance of our regression results and may not represent an exploitable trading strategy.
} 
the mean return on the Hedge Portfolio is only $0.12 \%$ and is statistically insignificant (pvalue $=0.93)$

\subsection{Sensitivity analysis}

This section reports the results of four sensitivity analyses. First, we augment equations (1) and (2) by adding nondiscretionary earnings (NDA) as an explanatory variable. ${ }^{10}$ If the observed correlation between CDACC and CAR is spurious and arises due to the correlation between CDACC and total accruals, NDA should also be correlated with CAR. The results in table 6 show that in both equations NDA and CAR are uncorrelated, whereas CDACC and CAR remain correlated as before. These results thus increase our confidence in the validity of our findings.

Second, we replicate our findings using alternative proxies for unexpected discretionary accruals. As explained earlier, we chose the seasonal difference in discretionary accruals as the proxy. However, it is arguable that investors expect quarterly discretionary accruals to be zero, and thus the level of the quarterly discretionary accruals is a more appropriate proxy for unexpected discretionary accruals. Additionally, as is standard in the literature, in the process of computing discretionary accruals we used the balance sheet approach to compute total accruals. However, Collins and Hribar [1999] argue that the difference between net income and cash from operations is the correct measure of total accruals and that the use of the balance sheet approach may under certain circumstances lead to a systematic bias in estimated discretionary accruals. To evaluate the effect of these two potential problems on our findings, we replicate our

\footnotetext{
${ }^{10} \mathrm{NDA}$ is expected accruals as a percentage of total assets, computed as total accruals minus unexpected discretionary accruals.
} 
regression tests, using CAR in period $(-1 F D,+15 F D)$, after replacing our proxy for unexpected discretionary accruals (CDACC) with the levels of quarterly discretionary accruals (DACC). In addition, we repeat this regression test using CDACC and DACC computed on the basis of the method advocated by Collins and Hribar [1999].

The results, displayed in Table 7 , show that when the proxy is based on the seasonal difference in discretionary accruals our findings are robust to the method in which total accruals are computed: the balance sheet approach and the Collins and Hribar [1999] approach generate remarkably similar results. However, when the proxy is based on the level of discretionary accruals, the results are much weaker, particularly when total accruals are computed using the Collins and Hribar [1999] approach. Overall, these results suggest that approximating total accruals by using the balance sheet approach has not biased our findings and that seasonal differences in discretionary accruals, not their levels, are the appropriate proxy for unexpected discretionary accruals.

Our third sensitivity analysis involves our categorization of high and low investor sophistication based on a $40 \%$ cutoff in institutional ownership. While this choice represents an effort to maximize the difference between the two subsamples in terms of institutional holdings while minimizing the difference in sample size, it is ad hoc and thus deserves further examination. In Table 8, we replicate the regression test of equation (2), using CAR in the period $(-1 F D,+15 F D)$, for alternative cutoff points ranging from 30 percent to 60 percent. The results show that the estimate on CDACC is robust to all choices for the cutoff point, while the estimate on CDACC*DINST becomes insignificant when the cutoff point is set to 60 percent. Overall, the results in Table 8 indicate that our findings are not driven by our choice of a 40 percent cutoff point. 
Our fourth and final sensitivity test evaluates our choice of the length of the return window around the 10-Q filing date. We used the period $(-1 \mathrm{FD},+15 \mathrm{FD})$ and found that the unsophisticated investors' reaction to the discretionary accruals news occurred during this 17-day period. However, it is arguable that a 17-day return window is too long, as the unsophisticated investors may have reacted to the discretionary accruals news soon after the filing of the 10-Q. To test for this possibility, we replicate the regression tests of equations (1) and (2) by measuring CAR using two alternative shorter windows around the 10-Q filing date: a three-day window $(-1 F D,+1 F D)$ and a seven-day window $(-1 F D$, +5 FD). Table 9 displays the results of this sensitivity analysis, which do not support this possibility. In both cases, none of the slope estimates are significantly different from zero at conventional levels, suggesting that a longer window is necessary for the unsophisticated investors to undo the earnings management.

\section{Concluding Remarks}

This study examines whether investors reassess the integrity of recently announced quarterly earnings using information provided in the full set of quarterly financial statements as it becomes available. We observe that the disaggregation of quarterly earnings into its discretionary and nondiscretionary components requires use of both income statement and balance sheet information, which is often not available to investors until Form 10-Q has been filed with the SEC. We therefore predict a negative association between the degree of accruals management and the stock price reaction around the 10-Q filing date. Using a sample of firms for which there is ex post evidence of accruals management, we document evidence consistent with this prediction. We also 
find that investor sophistication plays a role in determining the timing of the market reaction to accruals management, with the price reaction of sophisticated investors preceding that of unsophisticated ones. Overall, the results suggest that investors reassess reported quarterly earnings figures using other financial statement information and that this reassessment is associated with a substantial stock price change.

Possible extensions include examining the extent to which investors respond to accruals management in less obvious cases. For example, we focus on a sample of firms who just meet or barely beat consensus analyst forecasts. Do investors still recognize and respond to accruals management when reported earnings greatly exceed or fall short of earnings expectations? In addition, sophisticated investors in our sample were able to recognize accruals management prior to release of $10-\mathrm{Q}$ information. What is the mechanism by which they were able to accomplish this? Which particular pieces of information do they rely upon in making this judgment? These are just a few of the unanswered questions that might be explored in future research. 


\section{REFERENCES}

Bartov, E., S. Radhakrishnan, and I. Krinsky. 2000. Investor sophistication and patterns in stock returns after earnings announcements," The Accounting Review 75: 4363.

Brown, L. 1999. Managerial behavior and the bias in analysts' earnings forecasts. Working paper, Georgia State University.

Burgstahler, D., M. Eames. 1998. Management of earnings and analysts' forecasts. Working paper, University of Washington.

Collins, D.W., and P. Hribar. 1999. Errors in estimating accruals: Implications for empirical research, Working paper, University of Iowa.

Dechow, P., R. Sloan, and A. Sweeney. 1995. Detecting earnings management. The Accounting Review 70: 193-226.

DeFond, M.L., and J. Jiambalvo. 1994. Debt covenant violation and manipulation of accruals." Journal of Accounting and Economics 17: 145-176.

Degeorge, F., J. Patel, and R. Zeckhauser. 1999. Earnings management to exceed thresholds. Journal of Business 72: 1-33.

Guay, W., S. Kothari, and R. Watts. 1996. A market-based evaluation of discretionary accruals models. Journal of Accounting Research: 83-116.

Han, B. H., R. Jennings, and J. Noel. 1992. Communication of nonearnings information at the financial statements release date. Journal of Accounting and Economics 15, 63-86.

Jeter, D.C., and L. Shivakumar. 1999. Cross-sectional estimation of abnormal accruals using quarterly and annual data: effectiveness in detecting event-specific earnings management. Working paper, Vanderbilt University.

Levitt, A. 1998. The numbers game. Securities and Exchange Commission, Remarks by Chair Arthur Levitt at New York University Center of Law and Business (September 28). Available online at www.sec.gov/news/speeches/spch220.txt

Rajgopal, S., M. Venkatachalam, and J. Jiambalvo. 1999. Is Institutional Ownership Associated with Earnings Management and the Extent to which Stock Prices Reflect Future Earnings? Working paper, University of Washington.

Rangan, S. 1998. Earnings management and the performance of seasoned equity offerings. Journal of Financial Economics 50: 101-122. 
Subramanyam, K.R. 1996. The pricing of discretionary accruals. Journal of Accounting and Economics 22: 249-282.

Teoh S.H., I. Welch, and T.J. Wong. 1998a. Earnings management and the long run market performance of initial public offerings. The Journal of Finance 53: $1935-$ 1974.

Teoh S.H., I. Welch, and T.J. Wong. 1998b. Earnings management and the post-issue underperformance of seasoned equity offerings. Journal of Financial Economics 50: 63-100.

Walther, B., 1997, Investor sophistication and market earnings expectations, Journal of Accounting Research 35, 157-192. 
Table 1

Sample Selection

\begin{tabular}{|l|r|r|}
\hline & $\begin{array}{r}\text { Firm- } \\
\text { Quarter } \\
\text { Obs. }\end{array}$ & $\begin{array}{r}\text { Unique } \\
\text { Firms }\end{array}$ \\
\hline $\begin{array}{l}\text { Observations for first 3 quarters on Quarterly Compustat with fiscal year ends of } \\
\text { December 96 through 1998 }\end{array}$ & 37,708 & 5,709 \\
\hline $\begin{array}{l}\text { Observations for which discretionary accruals under the cross-sectional Jones model } \\
\text { could be computed }\end{array}$ & 19,078 & 3,001 \\
\hline $\begin{array}{l}\text { Observations for which unexpected discretionary accruals (estimate for quarter } t \text { minus } \\
\text { estimate for quarter } \text {-4) could be computed }\end{array}$ & 11,747 & 2,217 \\
\hline Observations on IBES* & 4,964 & 1,091 \\
\hline Observations that either meet or beat IBES forecast by 1 penny per share & 1,176 & 593 \\
\hline Observations where unexpected discretionary accruals exceed one percent of assets & 938 & 532 \\
\hline Observations with filing dates on EDGAR & 931 & 530 \\
\hline Observations with on time filing dates & 911 & 525 \\
\hline $\begin{array}{l}\text { Observations with filing dates at least twelve (trading) days after earnings } \\
\text { announcement }\end{array}$ & 636 & 375 \\
\hline Observations with CRSP data & 633 & 373 \\
\hline Observations with institutional ownership data on Compact Disclosure & 613 & 366 \\
\hline
\end{tabular}

\section{Observations by Quarter}

\begin{tabular}{|l|r|r|}
\hline First & 204 & 175 \\
\hline Second & 265 & 219 \\
\hline Third & 144 & 132 \\
\hline
\end{tabular}

Observations by Year

\begin{tabular}{|l|r|r|}
\hline 1996 & 157 & 126 \\
\hline 1997 & 248 & 189 \\
\hline 1998 & 208 & 176 \\
\hline
\end{tabular}

* IBES forecasts were available through the second quarter of 1998. 
Table 2

Descriptive Statistics

Panel A: Full Sample $(\mathrm{n}=613)$

\begin{tabular}{|c|c|c|c|c|c|c|c|c|}
\hline Variable & Mean & Minimum & $1^{\text {st }} Q$ & Median & $3^{\text {rd }} Q$ & Maximum & Std Dev & $\mathrm{CV}$ \\
\hline CAR & -0.002 & -0.319 & -0.064 & -0.009 & 0.056 & 0.315 & 0.098 & -46.110 \\
\hline DACC & 0.005 & -0.140 & -0.019 & 0.004 & 0.027 & 0.151 & 0.044 & 8.406 \\
\hline CDACC & 0.003 & -0.236 & -0.035 & 0.013 & 0.038 & 0.243 & 0.066 & 20.069 \\
\hline INST & 49.973 & 0.000 & 31.930 & 52.520 & 66.990 & 99.99 & 22.76 & 0.455 \\
\hline ASSETS & 3150.758 & 11.589 & 99.059 & 488.082 & 2459.64 & 54715.7 & 6560.41 & 2.082 \\
\hline ANALYSTS & 7.179 & 1.000 & 3.000 & 6.000 & 10.000 & 34.000 & 5.535 & 0.771 \\
\hline NUMDAY & 23.287 & 16.000 & 21.000 & 23.000 & 27.000 & 37.000 & 4.238 & 0.182 \\
\hline
\end{tabular}

Panel B: Firms in highest quartile of unexpected discretionary accruals $(n=154)$

\begin{tabular}{|c|c|c|c|c|c|c|c|c|}
\hline Variable & Mean & Minimum & $1^{\text {st }} Q$ & Median & $3^{\text {rd }} Q$ & Maximum & Std Dev & $\mathrm{CV}$ \\
\hline CAR & -0.015 & -0.319 & -0.076 & -0.013 & 0.046 & 0.315 & 0.110 & -7.179 \\
\hline DACC & 0.041 & -0.116 & 0.012 & 0.037 & 0.061 & 0.151 & 0.046 & 1.111 \\
\hline CDACC & 0.080 & 0.038 & 0.047 & 0.059 & 0.093 & 0.243 & 0.050 & 0.627 \\
\hline INST & 46.202 & 0.000 & 27.000 & 48.310 & 65.190 & 99.00 & 23.49 & 0.508 \\
\hline ASSETS & 2781.179 & 15.208 & 81.246 & 243.957 & 1253.93 & 36989.0 & 6681.58 & 2.402 \\
\hline ANALYSTS & 6.331 & 1.000 & 3.000 & 5.000 & 9.000 & 23.000 & 4.582 & 0.724 \\
\hline NUMDAY & 23.331 & 16.000 & 21.000 & 23.000 & 27.000 & 37.000 & 4.413 & 0.189 \\
\hline
\end{tabular}

Panel C: Firms in lowest quartile of unexpected discretionary accruals $(n=153)$

\begin{tabular}{|c|c|c|c|c|c|c|c|c|}
\hline Variable & Mean & Minimum & $1^{\text {st }} Q$ & Median & $3^{\text {rd }} Q$ & Maximum & Std Dev & $\mathrm{CV}$ \\
\hline CAR & 0.013 & -0.283 & -0.060 & -0.001 & 0.078 & 0.315 & 0.107 & 8.437 \\
\hline DACC & -0.031 & -0.140 & -0.054 & -0.026 & -0.009 & 0.087 & 0.040 & -1.298 \\
\hline CDACC & -0.075 & -0.236 & -0.086 & -0.060 & -0.043 & -0.035 & 0.046 & -0.615 \\
\hline INST & 47.079 & 0.000 & 28.260 & 51.400 & 66.120 & 99.99 & 23.87 & 0.507 \\
\hline ASSETS & 1994.801 & 11.589 & 76.968 & 201.397 & 1338.23 & 26360.9 & 4415.26 & 2.213 \\
\hline ANALYSTS & 6.412 & 1.000 & 3.000 & 5.000 & 8.000 & 29.000 & 5.374 & 0.838 \\
\hline NUMDAY & 23.118 & 16.000 & 21.000 & 23.000 & 25.000 & 35.000 & 4.186 & 0.181 \\
\hline
\end{tabular}

$\mathrm{CAR}=$ cumulative industry adjusted returns for 17 day window $(-1,15)$ surrounding the filing date of $10-\mathrm{Q}$ (i.e., day 0).

DACC $=$ discretionary accruals as a percentage of total assets for quarter under examination (i.e., quarter $t$ ), where discretionary accruals are calculated using the cross-sectional Jones model.

CDACC $=$ unexpected discretionary accruals as a percentage of total assets computed as discretionary accruals for the quarter under examination (i.e., quarter $t$ ) minus discretionary accruals for quarter $t-4$, where discretionary accruals are calculated using the cross-sectional Jones model.

INST $=$ percentage institutional shareholdings at the end of quarter $t$.

ASSETS $=$ total assets in millions at end of quarter $t$.

ANALYSTS $=$ number of analysts with forecasts on IBES in quarter $t$.

NUMDAY = number of days between the earnings announcement and the filing date of 10-Q. 
Table 3

Tests for the relation between unexpected discretionary accruals, investor sophistication, and abnormal stock returns around $10-\mathrm{Q}$ filing dates

( $p$-values for two-tailed tests beneath coefficients)

$(\mathrm{n}=613)$

$\mathrm{CAR}_{\mathrm{i}}=\alpha_{0}+\alpha_{1} \mathrm{CDACC}_{\mathrm{i}}+\alpha_{2} \mathrm{CDACC}_{\mathrm{i}} * \mathrm{DINST}_{\mathrm{i}}+\varepsilon_{\mathrm{i}}$

\begin{tabular}{|c|c|c|c|c|c|c|c|c|}
\hline \multirow[b]{2}{*}{ Variable } & \multicolumn{2}{|c|}{ CAR (-1EAD,9EAD) } & \multicolumn{2}{|c|}{$\mathrm{CAR}(+10 \mathrm{EAD},-2 \mathrm{FD})$} & \multicolumn{2}{|c|}{ CAR (-1FD,15FD) } & \multicolumn{2}{|c|}{ CAR (16FD,32FD) } \\
\hline & $\begin{array}{c}\text { Coefficient } \\
\text { p-value }\end{array}$ & $\begin{array}{c}\text { Coefficient } \\
\text { p-value }\end{array}$ & $\begin{array}{c}\text { Coefficient } \\
\text { p-value }\end{array}$ & $\begin{array}{c}\text { Coefficient } \\
\text { p-value }\end{array}$ & $\begin{array}{c}\text { Coefficient } \\
\text { p-value }\end{array}$ & $\begin{array}{c}\text { Coefficient } \\
\text { p-value }\end{array}$ & $\begin{array}{c}\text { Coefficient } \\
\text { p-value }\end{array}$ & $\begin{array}{c}\text { Coefficient } \\
\text { p-value }\end{array}$ \\
\hline \multirow[t]{2}{*}{ Intercept } & -0.00 & -0.00 & -0.00 & -0.00 & -0.00 & -0.00 & -0.00 & -0.00 \\
\hline & 0.44 & 0.44 & 0.39 & 0.42 & 0.66 & 0.60 & 0.77 & 0.79 \\
\hline \multirow[t]{2}{*}{ CDACC } & 0.06 & 0.05 & 0.00 & 0.07 & -0.11 & -0.24 & 0.03 & 0.09 \\
\hline & 0.30 & 0.56 & 0.97 & 0.13 & 0.07 & 0.00 & 0.68 & 0.35 \\
\hline CDACC* & & 0.03 & & -0.14 & & 0.27 & & -0.13 \\
\hline DINST & & 0.82 & & 0.03 & & 0.02 & & 0.35 \\
\hline CDACC + & & 0.08 & & -0.07 & & 0.03 & & -0.04 \\
\hline CDACC* & & 0.42 & & 0.08 & & 0.74 & & 0.68 \\
\hline DINST & & & & & & & & \\
\hline Adj. R-SQ & 0.17 & -0.14 & -0.16 & 0.44 & 0.38 & 1.04 & -0.14 & -0.16 \\
\hline & & & & & & & & \\
\hline F-Value & 1.07 & 0.56 & 0.00 & 2.35 & 3.31 & 4.20 & 0.17 & 0.52 \\
\hline & 0.30 & 0.57 & 0.97 & 0.10 & 0.07 & 0.02 & 0.68 & 0.59 \\
\hline
\end{tabular}

Dependent Variable: CAR is Cumulative Industry Adjusted Returns measured over four alternative windows: the day before through 9 days after the earnings announcement date (-1EAD, 9EAD); 10 days after earnings announcement through 2 days prior to $10-\mathrm{Q}$ filing date (10EAD, -2FD); the day before through 15 days after the $10-\mathrm{Q}$ filing $(-1 \mathrm{FD}, 15 \mathrm{FD})$; and 16 days after through 32 days after the 10 -Q filing (16FD, 32FD).

CDACC is unexpected discretionary accruals as a percentage of total assets computed as discretionary accruals for the quarter under examination (i.e., quarter $t$ ) minus discretionary accruals for quarter $t-4$, where discretionary accruals are calculated using the cross-sectional Jones model.

DINST is an indicator variable taking the value of one if institutional shareholdings is 40 percent or greater and zero otherwise. 
Table 4

Seventeen-day intervals around 10-Q filing dates mean cumulative industry adjusted returns (\%) ( $\mathrm{p}$-values for two-tailed tests beneath means)

\begin{tabular}{|c|c|c|c|c|c|}
\hline $\begin{array}{l}\text { Cumulation } \\
\text { Period }\end{array}$ & $\begin{array}{l}\text { Portfolio 1 } \\
(\mathrm{n}=153)\end{array}$ & $\begin{array}{l}\text { Portfolio 2 } \\
(\mathrm{n}=153)\end{array}$ & $\begin{array}{l}\text { Portfolio 3 } \\
(\mathrm{n}=153)\end{array}$ & $\begin{array}{l}\text { Portfolio 4 } \\
(\mathrm{n}=154)\end{array}$ & $\begin{array}{l}\text { Hedge } \\
\text { Portfolio } \\
(\mathrm{n}=307)\end{array}$ \\
\hline -1EAD, 9EAD & -1.36 & 0.22 & -0.19 & 0.17 & -1.53 \\
& 0.09 & 0.76 & 0.80 & 0.86 & 0.22 \\
\hline 10EAD, -2 FD & -0.36 & -0.11 & -0.25 & -0.03 & -0.33 \\
& 0.40 & 0.77 & 0.55 & 0.96 & 0.61 \\
\hline -1FD, 15FD & 1.27 & -0.27 & -0.31 & -1.53 & 2.80 \\
& 0.14 & 0.66 & 0.69 & 0.09 & 0.02 \\
\hline 16FD, 32FD & -0.73 & 0.73 & 0.13 & -0.63 & -0.10 \\
& 0.45 & 0.37 & 0.88 & 0.52 & 0.94 \\
\hline
\end{tabular}

Portfolio 1 consists of firms in the lowest quartile of unexpected discretionary accruals. Portfolio 2 consists of firms in the second lowest quartile of unexpected discretionary accruals. Portfolio 3 consists of firms in the third lowest quartile of unexpected discretionary accruals. Portfolio 4 consists of firms in the highest quartile of unexpected discretionary accruals. Hedge Portfolio represents long positions in Portfolio 1 and short positions in Portfolio 4. 
Table 5

Seventeen-day interval $(-1,15)$ around 10-Q filing dates mean cumulative industry adjusted returns $(\%)$ ( $\mathrm{p}$-values for two-tailed tests beneath means)

\begin{tabular}{|c|c|c|c|c|c|}
\hline $\begin{array}{l}\text { Institutional } \\
\text { Holdings }\end{array}$ & Portfolio 1 & Portfolio 2 & Portfolio 3 & Portfolio 4 & $\begin{array}{l}\text { Hedge } \\
\text { Portfolio }\end{array}$ \\
\hline $\begin{array}{c}\text { Less than or } \\
\text { Equal to } \\
40 \%\end{array}$ & $\begin{array}{c}0.08 \\
(\mathrm{n}=48)\end{array}$ & $\begin{array}{c}0.73 \\
(\mathrm{n}=49)\end{array}$ & $\begin{array}{c}0.54 \\
(\mathrm{n}=49)\end{array}$ & $\begin{array}{c}0.07 \\
(\mathrm{n}=49)\end{array}$ & $\begin{array}{c}0.01 \\
(\mathrm{n}=97)\end{array}$ \\
\hline $\begin{array}{c}\text { Greater than } \\
40 \%\end{array}$ & -0.08 & -0.18 & -0.68 & -0.20 & 0.12 \\
& 0.93 & 0.80 & 0.46 & 0.84 & 0.93 \\
$(\mathrm{n}=104)$ & $(\mathrm{n}=105)$ & $(\mathrm{n}=104)$ & $(\mathrm{n}=105)$ & $(\mathrm{n}=209)$ \\
\hline
\end{tabular}

Portfolio 1 consists of firms in the lowest quartile of unexpected discretionary accruals. Portfolio 2 consists of firms in the second lowest quartile of unexpected discretionary accruals. Portfolio 3 consists of firms in the third lowest quartile of unexpected discretionary accruals. Portfolio 4 consists of firms in the highest quartile of unexpected discretionary accruals. Hedge Portfolio represents long positions in Portfolio 1 and short positions in Portfolio 4. 
Table 6

Tests for the relation between unexpected discretionary accruals, nondiscretionary accruals, investor sophistication, and abnormal stock returns around 10-Q filing dates

( $\mathrm{p}$-values for two-tailed tests beneath coefficients)

$(n=613)$

$\mathrm{CAR}_{\mathrm{i}}=\alpha_{0}+\alpha_{1} \mathrm{CDACC}_{\mathrm{i}}+\alpha_{2} \mathrm{NDA}_{\mathrm{i}}+\alpha_{3} \mathrm{CDACC}_{\mathrm{i}} * \mathrm{DINST}_{\mathrm{i}}+\varepsilon_{\mathrm{i}}$

\begin{tabular}{|c|c|c|c|}
\hline \multirow[b]{2}{*}{ Variable } & \multicolumn{3}{|c|}{$\operatorname{CAR}(-1,15)$} \\
\hline & $\begin{array}{c}\text { Coefficient } \\
\text { p-value }\end{array}$ & $\begin{array}{l}\text { Coefficient } \\
\text { p-value }\end{array}$ & $\begin{array}{l}\text { Coefficient } \\
\text { p-value }\end{array}$ \\
\hline Intercept & $\begin{array}{r}-0.00 \\
0.61 \\
\end{array}$ & $\begin{array}{r}-0.00 \\
0.57 \\
\end{array}$ & $\begin{array}{r}-0.00 \\
0.53 \\
\end{array}$ \\
\hline CDACC & $\begin{array}{r}-0.15 \\
0.08\end{array}$ & $\begin{array}{r}-0.27 \\
0.01\end{array}$ & $\begin{array}{r}-0.21 \\
0.07\end{array}$ \\
\hline NDA & $\begin{array}{r}-0.07 \\
0.50\end{array}$ & $\begin{array}{r}-0.06 \\
0.57\end{array}$ & $\begin{array}{l}0.05 \\
0.72\end{array}$ \\
\hline $\begin{array}{l}\text { CDACC* } \\
\text { DINST }\end{array}$ & & $\begin{array}{l}0.27 \\
0.03\end{array}$ & $\begin{array}{l}0.11 \\
0.53\end{array}$ \\
\hline $\begin{array}{l}\text { NDA* } \\
\text { DINST }\end{array}$ & & & $\begin{array}{r}-0.24 \\
0.22\end{array}$ \\
\hline $\begin{array}{l}\text { CDACC + } \\
\text { CDACC* } \\
\text { DINST }\end{array}$ & & $\begin{array}{l}0.00 \\
0.96\end{array}$ & $\begin{array}{r}-0.10 \\
0.46\end{array}$ \\
\hline $\begin{array}{l}\mathrm{NDA}+ \\
\mathrm{NDA} * \mathrm{INST}\end{array}$ & & & $\begin{array}{r}-0.19 \\
0.19 \\
\end{array}$ \\
\hline Adj. R-SQ (\%) & 0.29 & 0.93 & 1.01 \\
\hline F-Value & $\begin{array}{l}1.88 \\
0.15 \\
\end{array}$ & $\begin{array}{l}2.91 \\
0.03 \\
\end{array}$ & $\begin{array}{l}2.56 \\
0.04\end{array}$ \\
\hline
\end{tabular}

Dependent Variable: CAR is Cumulative Industry Adjusted Returns measured over 17-day window (-1,15), where day 0 is the filing date of $10-\mathrm{Q}$.

CDACC is unexpected discretionary accruals as a percentage of total assets computed as discretionary accruals for the quarter under examination (i.e., quarter $t$ ) minus discretionary accruals for quarter $t$-4, where discretionary accruals are calculated using the cross-sectional Jones model.

NDA is expected accruals as a percentage of total assets computed as total accruals minus unexpected discretionary accruals.

DINST is an indicator variable taking the value of one if institutional shareholdings is 40 percent or greater and zero otherwise. 
Table 7

Tests for the relation between alternative discretionary accrual measures and abnormal stock returns around 17 day window $(-1,15)$ surrounding 10-Q filing date

( $\mathrm{p}$-values for two-tailed tests beneath coefficients)

$(n=613)$

Panel A: $\mathrm{CAR}_{\mathrm{i}}=\alpha_{0}+\alpha_{1}$ Discretionary Accrual Measure $_{\mathrm{i}}+\varepsilon_{\mathrm{i}}$

\begin{tabular}{|l||c||c||r||r||}
\hline \multicolumn{1}{|c||}{ Variable } & $\begin{array}{c}\text { Change in } \\
\text { Discretionary } \\
\text { Accruals } \\
\text { (DACC) }\end{array}$ & $\begin{array}{c}\text { Collins and } \\
\text { Discretionary } \\
\text { Accruals } \\
\text { (CDACC) }\end{array}$ & $\begin{array}{c}\text { Hribar } \\
\text { (1999) } \\
\text { (DACC2) }\end{array}$ & $\begin{array}{c}\text { Hribar (1999) } \\
\text { (CDACC2) }\end{array}$ \\
\cline { 2 - 5 } & $\begin{array}{c}\text { Coefficient } \\
\text { p-value }\end{array}$ & $\begin{array}{c}\text { Coefficient } \\
\text { p-value }\end{array}$ & $\begin{array}{c}\text { Coefficient } \\
\text { p-value }\end{array}$ & $\begin{array}{c}\text { Coefficient } \\
\text { p-value }\end{array}$ \\
\hline Intercept & -0.00 & -0.00 & -0.00 & -0.00 \\
& 0.77 & 0.66 & 0.58 & 0.34 \\
\hline Discretionary & -0.18 & -0.11 & -0.09 & 0.12 \\
Accrual Measure & 0.04 & 0.07 & 0.17 & 0.02 \\
\hline Adj. R-SQ (\%) & 0.52 & 0.38 & 0.15 & 5.57 \\
\hline F-Value & 4.18 & 3.31 & 1.90 & 0.02 \\
\hline
\end{tabular}

Panel B: CAR $_{\mathrm{i}}=\alpha_{0}+\alpha_{1}$ Discretionary Accrual Measure $_{\mathrm{i}}+\alpha_{2}$ Discretionary Accrual Measure $_{\mathrm{i}} *$ DINST $+\varepsilon_{\mathrm{i}}$

\begin{tabular}{|c|c|c|c|c|}
\hline Variable & $\begin{array}{c}\text { Discretionary } \\
\text { Accruals } \\
\text { (DACC) }\end{array}$ & $\begin{array}{c}\text { Change in } \\
\text { Discretionary } \\
\text { Accruals } \\
\text { (CDACC) }\end{array}$ & $\begin{array}{l}\text { Collins and } \\
\text { Hribar } \\
(1999) \\
\text { (DACC2) }\end{array}$ & $\begin{array}{l}\text { Collins and } \\
\text { Hribar (1999) } \\
\text { (CDACC2) }\end{array}$ \\
\hline & $\begin{array}{c}\text { Coefficient } \\
\text { p-value }\end{array}$ & $\begin{array}{c}\text { Coefficient } \\
\text { p-value }\end{array}$ & $\begin{array}{c}\text { Coefficient } \\
\text { p-value }\end{array}$ & $\begin{array}{c}\text { Coefficient } \\
\text { p-value }\end{array}$ \\
\hline Intercept & $\begin{array}{r}-0.00 \\
0.76\end{array}$ & $\begin{array}{r}-0.00 \\
0.60\end{array}$ & $\begin{array}{r}-0.00 \\
0.58\end{array}$ & $\begin{array}{r}-0.00 \\
0.30\end{array}$ \\
\hline $\begin{array}{l}\text { Discretionary } \\
\text { Accrual Measure }\end{array}$ & $\begin{array}{r}-0.26 \\
0.04\end{array}$ & $\begin{array}{r}-0.24 \\
0.00\end{array}$ & $\begin{array}{r}-0.10 \\
0.35\end{array}$ & $\begin{array}{r}-0.28 \\
0.00\end{array}$ \\
\hline $\begin{array}{l}\text { Discretionary } \\
\text { Accrual } \\
\text { Measure*DINST }\end{array}$ & $\begin{array}{l}0.15 \\
0.40\end{array}$ & $\begin{array}{l}0.27 \\
0.02\end{array}$ & $\begin{array}{l}0.02 \\
0.91\end{array}$ & $\begin{array}{l}0.29 \\
0.01\end{array}$ \\
\hline $\begin{array}{l}\text { Discretionary } \\
\text { Accrual Measure } \\
+ \text { Discretionary } \\
\text { Accrual } \\
\text { Measure*DINST }\end{array}$ & $\begin{array}{r}-0.11 \\
0.36\end{array}$ & $\begin{array}{l}0.03 \\
0.74\end{array}$ & $\begin{array}{r}-0.08 \\
0.29\end{array}$ & $\begin{array}{l}0.01 \\
0.92\end{array}$ \\
\hline Adj. R-SQ (\%) & 0.47 & 1.04 & -0.01 & 1.86 \\
\hline F-Value & $\begin{array}{l}2.45 \\
0.09\end{array}$ & $\begin{array}{l}4.20 \\
0.02\end{array}$ & $\begin{array}{l}0.96 \\
0.39 \\
\end{array}$ & $\begin{array}{l}6.79 \\
0.01 \\
\end{array}$ \\
\hline
\end{tabular}

Dependent Variable: CAR is Cumulative Industry Adjusted Returns measured over the 17-day window $(-1,15)$, where day 0 is the filing date of $10-\mathrm{Q}$.

CDACC is unexpected discretionary accruals as a percentage of total assets computed as discretionary accruals for the quarter under examination (i.e., quarter $t$ ) minus discretionary accruals for quarter $t$-4, where discretionary accruals are calculated using the cross-sectional Jones model. 
DACC is discretionary accruals as a percentage of total assets for quarter under examination (i.e., quarter $t$ ), where discretionary accruals are calculated using the cross-sectional Jones model.

CDACC2 is unexpected discretionary accruals as a percentage of total assets computed as discretionary accruals for the quarter under examination (i.e., quarter $t$ ) minus discretionary accruals for quarter $t-4$, where discretionary accruals are calculated using the cross-sectional Jones model. Total accruals are defined using Collins and Hribar (1999) model.

DACC2 is discretionary accruals as a percentage of total assets for quarter $t-4$, where discretionary accruals are calculated using the cross-sectional Jones model. Total accruals are defined using Collins and Hribar (1999) model.

DINST is an indicator variable taking the value of one if institutional shareholdings is 40 percent or greater and zero otherwise. 
Table 8

Tests for the relation between unexpected discretionary accruals, alternative measures of investor sophistication, and abnormal stock returns around 10-Q filing dates

( $\mathrm{p}$-values for two-tailed tests beneath coefficients)

$(n=613)$

Panel A: $\mathrm{CAR}_{\mathrm{i}}=\alpha_{0}+\alpha_{1} \mathrm{CDACC}_{\mathrm{i}}+\alpha_{2} \mathrm{CDACC}_{\mathrm{i}} * \mathrm{DINST}_{\mathrm{i}}+\varepsilon_{\mathrm{i}}$

\begin{tabular}{|c|c|c|c|c|c|}
\hline \multirow[b]{2}{*}{ Variable } & \multicolumn{5}{|c|}{$\operatorname{CAR}(-1,15)$} \\
\hline & $\begin{array}{c}\text { Coefficient } \\
\text { p-value }\end{array}$ & $\begin{array}{c}\text { Coefficient } \\
\text { p-value }\end{array}$ & $\begin{array}{l}\text { Coefficient } \\
\text { p-value }\end{array}$ & $\begin{array}{l}\text { Coefficient } \\
\text { p-value }\end{array}$ & $\begin{array}{c}\text { Coefficient } \\
\text { p-value }\end{array}$ \\
\hline \multirow[t]{2}{*}{ Intercept } & -0.00 & -0.00 & -0.00 & -0.00 & -0.00 \\
\hline & 0.66 & 0.68 & 0.60 & 0.67 & 0.68 \\
\hline \multirow[t]{2}{*}{ CDACC } & -0.11 & -0.26 & -0.24 & -0.20 & -0.16 \\
\hline & 0.07 & 0.01 & 0.00 & 0.01 & 0.02 \\
\hline $\mathrm{CDACC}^{*}$ & & 0.23 & & & \\
\hline DINST & & 0.06 & & & \\
\hline $\mathrm{CDACC}^{*}$ & & & 0.27 & & \\
\hline DINST & & & 0.02 & & \\
\hline ( $40 \%$ or higher) & & & & & \\
\hline CDACC* & & & & 0.24 & \\
\hline DINST & & & & 0.05 & \\
\hline (50\% or higher) & & & & & \\
\hline $\mathrm{CDACC}^{*}$ & & & & & 0.21 \\
\hline DINST & & & & & 0.12 \\
\hline ( $60 \%$ or higher) & & & & & \\
\hline $\mathrm{CDACC}+$ & & -0.03 & 0.03 & 0.04 & 0.05 \\
\hline $\mathrm{CDACC}^{*}$ & & 0.79 & 0.74 & 0.71 & 0.75 \\
\hline DINST & & & & & \\
\hline Adj. R-SQ (\%) & 0.38 & 0.79 & 1.04 & 0.85 & 0.60 \\
\hline F-Value & 3.31 & 3.43 & 4.20 & 3.64 & 2.84 \\
\hline & 0.07 & 0.03 & 0.02 & 0.03 & 0.06 \\
\hline
\end{tabular}

Dependent Variable: CAR is Cumulative Industry Adjusted Returns measured over the 17-day window (-1,15), where day 0 is the filing date of $10-\mathrm{Q}$.

CDACC is unexpected discretionary accruals as a percentage of total assets computed as discretionary accruals for the quarter under examination (i.e., quarter $t$ ) minus discretionary accruals for quarter $t-4$, where discretionary accruals are calculated using the cross-sectional Jones model.

DINST is an indicator variable taking the value of one if institutional shareholdings is greater than 30 (or 40 , 50 , or 60) percent and zero otherwise. 
Table 9

Tests for the relation between unexpected discretionary accruals, investor sophistication, and alternative abnormal stock return windows around 10-Q filing dates (p-values for two-tailed tests beneath coefficients) $(n=613)$

Panel A: $\mathrm{CAR}_{\mathrm{i}}=\alpha_{0}+\alpha_{1} \mathrm{CDACC}_{\mathrm{i}}+\alpha_{2} \mathrm{CDACC}_{\mathrm{i}} * \mathrm{DINST}_{\mathrm{i}}+\varepsilon_{\mathrm{i}}$

\begin{tabular}{|l|r|r|r|r|}
\hline \multirow{2}{*}{ Variable } & \multicolumn{2}{|c|}{ CAR $(-1,1)$} & \multicolumn{2}{c|}{ CAR $(-1,5)$} \\
\cline { 2 - 5 } & $\begin{array}{c}\text { Coefficient } \\
\text { p-value }\end{array}$ & $\begin{array}{c}\text { Coefficient } \\
\text { p-value }\end{array}$ & $\begin{array}{c}\text { Coefficient } \\
\text { p-value }\end{array}$ & $\begin{array}{c}\text { Coefficient } \\
\text { p-value }\end{array}$ \\
\hline Intercept & 0.00 & 0.00 & 0.00 & 0.00 \\
& 0.88 & 0.90 & 0.73 & 0.76 \\
\hline CDACC & -0.02 & -0.03 & -0.03 & -0.08 \\
& 0.37 & 0.32 & 0.45 & 0.13 \\
\hline CDACC* & & 0.02 & & 0.10 \\
DINST & & 0.63 & & 0.17 \\
\hline CDACC+CDACC* & & -0.01 & & 0.02 \\
DINST & & 0.80 & & 0.67 \\
\hline Adj. R-SQ (\%) & -0.03 & -0.15 & -0.07 & 0.08 \\
\hline F-Value & 0.82 & 0.53 & 0.57 & 1.25 \\
& 0.37 & 0.59 & 0.45 & 0.29 \\
\hline
\end{tabular}

Dependent Variable: CAR is Cumulative Industry Adjusted Returns measured over the $(-1,1)$ and $(-1,5)$ day windows surrounding the filing of the $10-\mathrm{Q}$, where day 0 is the filing date of $10-\mathrm{Q}$.

CDACC is unexpected discretionary accruals as a percentage of total assets computed as discretionary accruals for the quarter under examination (i.e., quarter $t$ ) minus discretionary accruals for quarter $t-4$, where discretionary accruals are calculated using the cross-sectional Jones model.

DINST is an indicator variable taking the value of one if institutional shareholdings is greater than 40 percent and zero otherwise. 